\title{
ATS HYBRID SYSTEM WITH PLTS AND PLN POWER FOR IOT-BASED HYDROPONIC PUMPS
}

\section{SISTEM ATS HYBRID DENGAN DAYA PLTS DAN PLN UNTUK POMPA HIDROPONIK BERBASIS IOT}

\author{
Indrianto Nugroho ${ }^{1}$, Jamaaluddin ${ }^{2}$ \\ \{ Indrianto1982@gmail.com ${ }^{1}$,jamaaluddin@umsida.ac.id $\left.{ }^{2}\right\}$ \\ ${ }^{1,2}$ Teknik Elektro, Fakultas Sains dan Teknologi \\ Universitas Muhammadiyah Sidoarjo
}

\begin{abstract}
Science and Technology for Hydroponics can be use in a limited land areas. This Hydroponic System usesa pump load to drain water continuously using PLN power and result in a waste of electricity costs. therefore this study applies a Hybrid ATS (Automatic Transfer Switch) System using PLTS power and PLN power for pump loads that drain water continuously using internet of things technology so that it can be monitored at any time. The ATS System performs Automatic Switching (disconnect flow a electric) If the PLTS power less than $<10 \mathrm{~V}$ and connects PLN power so that that the pump load remains on until the PLTS power recovers and the Blynk application sends a notification that the PLTS flow condition is cut off and PLN is connected. Error reading from the INA219 sensor at the voltage output is $0.4-0.6 \%$ and the current is 3.0\%. The TDS sensor reads the PPM value of hydroponic water from 08.00 to 18.00 with an average of 291.38 PPM.
\end{abstract}

Keywords - Science and Technology; ATS System; Hidroponics; Internet Of Things

Abstrak. Sains dan Teknologi untuk Hidroponik bisa dimanfaatkan di Wilayah lahan yang terbatas. Sistem Hidroponik ini menggunakan beban Pompa untuk mengalirkan air secara terus menerus dengan menggunakan Daya PLN dan mengakibatkan pemborosan biaya listrik. oleh karena itu Penelitian ini menerapkan Sistem ATS(Automatic Transfer Switch) Hybrid dengan menggunakan Daya PLTS dan Daya PLN untuk beban Pompa yang mengalirkan air terus menerus dengan menggunakan teknologi Internet Of Things supaya bisa memonitoring setiap waktu. Sistem ATS melakukan Switching Otomatis(memutus aliran listrik) Jika Daya PLTS melemah kurang <10V dan menghubungkan Daya PLN supaya Beban Pompa tetap menyala sampai Daya PLTS pulih kembali dan Aplikasi Blynk mengirim Notifikasi bahwa Kondisi Aliran PLTS terputus dan PLN terhubung. Kesalahan Pembacaan dari Sensor INA219 pada keluaran Tegangan sebesar 0.4 - 0,6\% dan Arus sebesar 3.0\%. Sensor TDS membaca nilai PPM air Hidroponik dari Pukul 08.00 sampai 18.00 dengan Rata-Rata 291,38 PPM.

Kata Kunci - Sains dan Teknologi; Sistem ATS; Hidroponik; Internet Of Things

\section{Pendahuluan}

Penggunaan Daya listrik di zaman millenial sekarang akan semakin tinggi .Karena pada dasarnya akan selalu membutuhkan energi listrik kapanpun dan dimanapun[1]. kehidupan setiap hari energi listrik ini juga bisa dikontrol untuk memudahkan penggunanya, dengan adanya sistem kontrol yang setiap waktu akan terjadi perkembangan yang sangat cepat[2].

Sains dan Teknologi untuk Hidroponik bisa dimanfaatkan di wilayahnya yang lahannya sangat minim. Sistemnya menggunakan tenaga penyuplai air berupa pompa yang di salurkan ke tanaman setiap waktu supaya tanaman bisa bertumbuh baik dan siap untuk di panen tetapi pada umumnya masyarakat hanya menggunakan tenaga listrik dari PLN dan Penggunaan daya dari energi alternatif seperti sistem PLTS masih sedikit yang menggunakan[3]. Maka karena itulah dibuat perancangan alat yang diberi judul Sistem ATS Hybrid Dengan Daya PLTS Dan PLN Untuk Pompa Hidroponik Berbasis Iot(Internet Of Things).

Penelitian ini menerapkan sistem Automatic Transfer Switch (ATS) arus listrik hybrid daya PLTS dengan backup daya dari PLN adaptor yang bertegangan DC dimana keluarannya di baca oleh Sensor INA219 nantinya dikontrol oleh relay yang akan di proses oleh Mikrokontroller NodeMCU dan akan menampilkan interface blynk untukmemonitoring tegangan dengan internet dan menghidupkan/mematikan pompa secara otomatis ,Pompa yang digunakan untuk Hidroponik adalah Pompa Submersible dan NonSubmersible bertegangan 12VDC beserta menggunakan Sensor TDS untuk mengetahui kualitas PPM pada air yang mengalir pada bak air ke Tanaman Hidroponik.

Energi Panas ialah Energi dihasilkan oleh Matahari. Energi yang dipancarkan dari matahari berupa radiasi cahaya yang berbentuk gelombang Elektromagnetik pendek yang tidak semuanya dapat ditangkap dengan penglihatan mata telanjang[4].

Sistem PLTS merupakan sistem yang bisa memanfaatkan cahaya radiasi matahari dengan menggunakan selsurya untuk dikonversikan energi listrik bertegangan DC untuk menyuplai daya ke beban Pompa yang mengalirkan Air Hidroponik, Sistem PLTS ini terdiri dari Sel surya, Solar Control Charger, Baterai, dan beban[5]. 
Panel Surya merupakan komponen alat yang bisa merubah radiasi matahari menjadi daya energi kelistrikan dengan prinsip efek Photovoltaic. Photovoltaic ini merupakan efek yang dimana fenomenanya muncul daya listrik dikarenakan ada hubungan dari 2 elektroda yang disatukan dengan sistem kepadatan waktu mendapat radiasi cahaya. Panel Matahari atau Panel Surya sering disebut Sel (PV) Photovoltaic. efek yang ditimbulkan Photovoltaic ditemui dari Henri Becquerel pada saat tahun 1839[6].

Sistem ATS (Automatic Transfer Switch) merupakan Suatu alat pemindah (Transfer) sumber daya dari sumber utama PLTS ke PLN. Automatic Transfer Switch akan mengembalikan pasokan tenaga ke posisi normal secara otomatis apabila Daya PLTS telah pulih Kembali[7][8].

Sistem Hidroponik untuk penduduk kota sangat dibutuhkan. karena wilayah di perkotaan banyak kekuranganseperti lahan terbatas, waktu yang kurang. Hidroponik memerlukan Motor Pompa yang berfungsi mengaliri air ke tanaman[3].

Pompa air merupakan suatu perabotan listrik yang dipakai pada masyarakat umum supaya bisa memenuhi kebutuhannya sehari-hari. Pompa ini mempunyai fungsi sebagai penghisapan dan mengaliri air dari suatu tempat ke tempat yang dituju. Prinsip kerjanya ialah mengubah energy mekanik dari penggeraknya yang menjadi energy potensial yang berupa head, maka zat cair ini mempunyai tekanan yang sesuai dengan head[9].

NodeMCU ialah board mikrokontroller mempunyai chip ESP8266 memiliki kelebihan sebagai mikrocontroller yang tersambung internet. memiliki pin Input/Output maka bisa dimanfaatkan sebuah aplikasi untukmemonitoring dan mengontrol pada project Internet Of Things. Komponen ini bisa di program dengan compiling dariArduino. NodeMCU memiliki port USB (USB mini) supaya pengguna dimudahkan memprogramnya[10].

Sensor INA219 merupakan sensor yang berfungsi untuk mengukur 2 parameter sekaligus yaitu tegangan (V) dan arus (A). Tegangan yang dapat diukur yaitu maksimal 26VDC sedangkan untuk arusnya maksimal sampai 3,2 A. Untuk komunikasinya sensor ini menggunakan I2C yaitu SDA dan SCL.

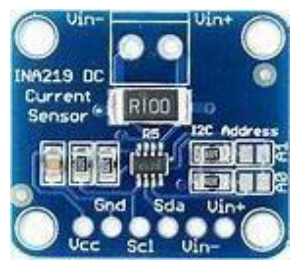

Gambar 1. Sensor INA219

Sensor TDS (Total Dissolved Solid) yang berfungsi mengukur bahan padat cair satuan PPM(parts per million). Jika terdapat banyak bahan padat didalam suatu bak air nilai pengukuran TDS akan meninggi dan Jika terdapat sedikit bahan-bahan padat yang terlarut maka semakin rendah nilai pengukuran TDS. Hasil keluaran nilai pengukuran sensor TDS terdapat pada Probe . kemudian nilai keluaran dari Pembacaan akan didata oleh Mikrokontroller NodeMCU[11].

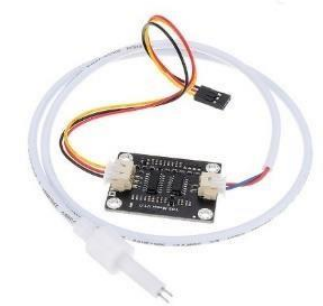

Gambar 2. Sensor TDS[11]

Sensor TDS menggunakan Tegangan input dari NodeMCU yang akan digunakan untuk Vref(tegangan referensi) dan melakukan pengukuran nilai Analog Digital Converter(ADC), selanjutnya keluaran nilai analog pada probe. Listrik dialirkan pada probe yang mempunyai 2 elektroda berbeda yang dicelupkan dalam cairan, kemudian arus yang timbul disebabkan oleh perpindahan ion pada konduktivitas pada cairan. Pengukuran conductivities pada sensor bergantung suhu referensi sekitar $25^{\circ} \mathrm{C}[11]$. 
Procedia of Engineering and Life Science Vol. 1 No.1 March 2021

Seminar Nasional \& Call Paper Fakultas Sains dan Teknologi (SENASAINS 1st)

Universitas Muhammadiyah Sidoarjo

\section{METODE}

A. Penelitian ini dilaksanakan beberapa Tahapan sebagai berikut :

1. Tahap Pertama yaitu menyediakan Komponen yang dibutuhkan untuk Perancangan

2. Tahap Kedua yaitu melakukan Perancangan Panel PV, SCC, Aki, perancangan Sistem ATS, Sensor TDS dan Mikrokontroller NodeMCU.

3. Tahap ketiga yaitu melakukan beberapa uji coba daya keluaran PLTS, adaptor PLN, Beban pompa, Mikrokontroller NodeMCU ,LCD 16x2 I2C ,Sensor TDS dan sensor INA219.

4. Tahap keempat yaitu Pengujian Sensor TDS. Pada tahap ini Rangkaian sudah terancang dan melakukan pengujian kualitas air pada Tanaman hidroponik

5. Tahap kelima yaitu Pengujian ATS. Pada tahap ini Rangkaian sudah terancang dari sumber daya alternatif PLTS dan sudah ada backup dari daya adaptor PLN yang akan menggantikan daya PLTS jika sudah melemah.

B. Diagram Blok Sistem

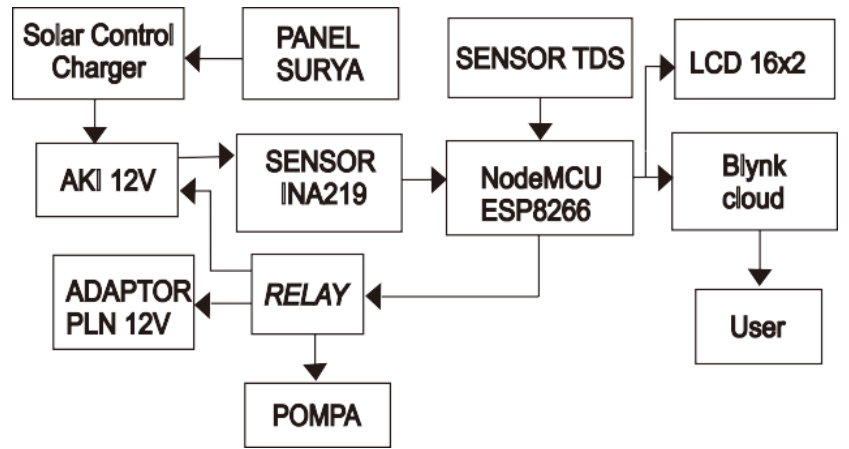

Gambar 3. Diagram Blok Sistem

\section{Flowchart Sistem}

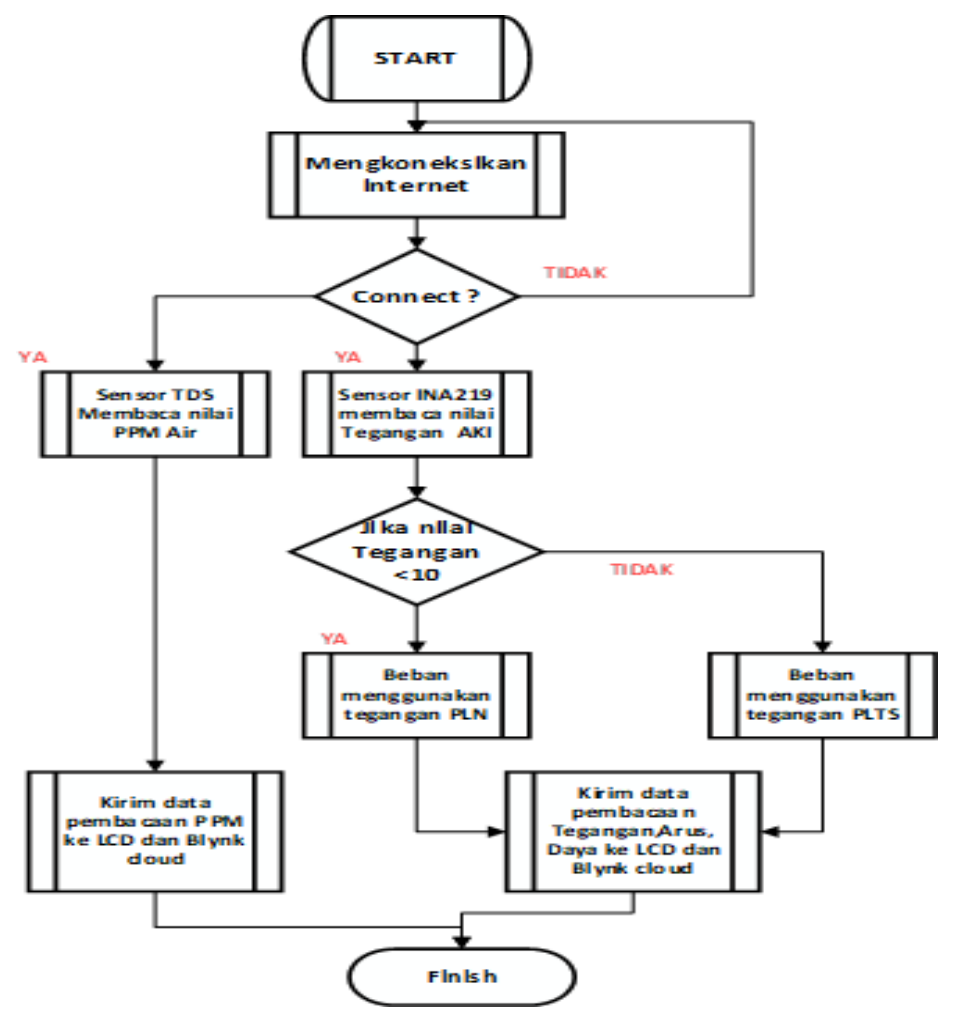

Gambar 4. Flowchart Sistem 
Procedia of Engineering and Life Science Vol. 1 No.1 March 2021

Seminar Nasional \& Call Paper Fakultas Sains dan Teknologi (SENASAINS 1st)

Universitas Muhammadiyah Sidoarjo

Penjelasan Flowchart diatas adalah :

1. Start melakukan Penyettingan Autentikasi, Ssid dan Password Wifi dan Mengupload Code yang sudah dibuat pada Software Arduino

2. Jika belum terhubung, maka melakukan penyettingan kembali pada Software Arduino.

3. Jika sudah terhubung dengan internet wifi, Sensor INA219 dan Sensor TDS akan melakukan sensing (Pembacaan).

4. Sensor TDS akan membaca nilai PPM air pada tanaman Hidroponik.

5. Sensor INA219 akan membaca nilai keluaran tegangan dan Arus Aki.

6. Jika Sensor INA219 membaca tegangan kurang <10VDC, maka Sensor mengirim data ke NodeMCU untuk memerintahkan Relay menghubungkan aliran listrik daya PLN adaptor lalu memutus aliran listrik daya PLTS dan Beban Pompa menggunakan daya PLN

7. Jika Sensor INA219 membaca tegangan lebih >10VDC ,maka Sensor mengirim data ke NodeMCU untuk memerintahkan Relay menghubungkan aliran listrik daya PLTS lalu memutus aliran listrik daya PLN adaptor dan Beban menggunakan daya PLTS

8. Nilai keluaran pada Tegangan, Arus, Daya dan PPM akan ditampilkan pada LCD 16X2 I2C dan aplikasi Blynk supaya bisa dimonitoring setiap waktu.

9. Finish

\section{Rangkaian Sistem Keseluruhan}

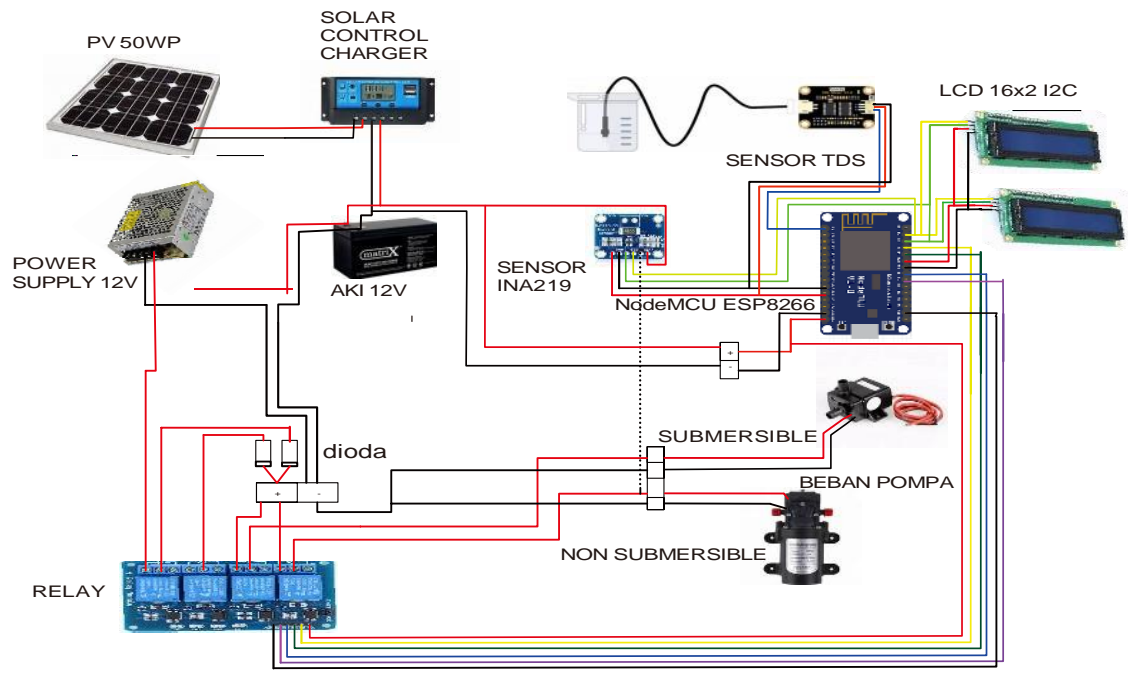

Gambar 5. Rangkaian Sistem Keseluruhan

Pada Gambar 5 meliputi penjelasan masing-masing dari komponen sebagai berikut :

1. Panel surya yang dipakai sebesar 50Wp untuk mengubah energi matahari menjadi energi listrik Tegangan DC sebesar $12 \mathrm{~V}$.

2. SCC berfungsi untuk pengecasan Aki jika terkena paparan sinar matahari

3. Aki berfungsi penyuplai daya ke beban

4. Powersupply 12VDC sebagai pengganti daya beban jika Aki sudah melemah kurang dari <10VDC.

5. Sensor INA219 untuk membaca nilai tegangan yang keluar dari Aki untuk mengirim data jika Tegangan kurang/lebih dari $><10$ VDC dan juga mengukur arus beban

6. Sensor TDS untuk membaca nilai kualitas air yang terdapat pada tanaman Hidroponik dengan satuan PPM

7. Relay berfungsi penghubung/pemutus aliran listrik dari Sistem ATS dan menghidupkan/mematikan beban pompa lewat internet menggunakan aplikasi Blynk

8. Dioda untuk menyearahkan tegangan inputan dari daya ke beban .

9. NodeMCU akan mengirimkan data ke Blynk dan LCD 16x2 I2C untuk menampilkan nilai Output daya PLTS dan nilai PPM air pada tanaman Hidroponik 
Procedia of Engineering and Life Science Vol. 1 No.1 March 2021

Seminar Nasional \& Call Paper Fakultas Sains dan Teknologi (SENASAINS 1st)

Universitas Muhammadiyah Sidoarjo

\section{HaSil dan Pembahasan}

\section{A. Desain Sistem Alat yang sudah dirancang}
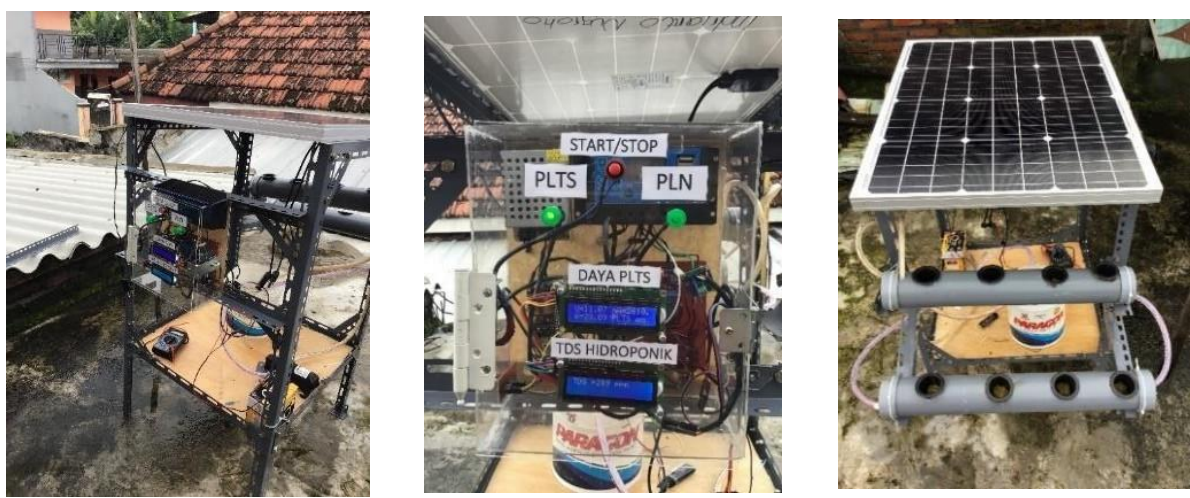

Gambar 6. Desain Sistem yang sudah dirancang

Sistem alat yang sudah dirancang akan dilakukan Pengujian dan Pembahasan. Tahap ini melakukan Pengujian supaya mengetahui cara kerja beserta mengetahui Keluaran pada Perancangan sistem dan Pengambilan data dilakukan pada bagian-bagian secara keseluruhan nantinya akan dianalisa.

\section{B. Pengujian Sistem ATS(Automatic Transfer Switch)}

Pada tahap ini dilakukan pengujian perpemindahan beban dari catu daya utama PLTS ke catu daya cadangan Adaptor PLN secara otomatis Jika sumber daya dari PLTS melemah kurang dari 10VDC . Dengan ini supaya pengguna tidak melakukan switching manual pada Sumber Daya listrik. Pengujian ini dilakukan untuk mengetahui apakah sistem ATS dapat berfungsi secara normal. Prosedur pengujian Sistem ATS yaitu :

1. Menekan Tombol Start pada Panel Box mini, saat kondisi starting Mikrokontroller NodeMCU melakukan pengkoneksian dengan aplikasi Blynk dengan terhubung internet dan memproses data dari Sensor INA219 dan Sensor TDS.

2. Jika Pada Lampu indikator PLTS menyala dan lampu indikator PLN mati, maka menandakan Daya PLTS terhubung menyuplai ke beban dan Daya PLN terputus dan juga sebaliknya.

3. Ketika Tegangan PLTS melemah kurang <10VDC maka Sensor INA219 akan mengirim data ke NodeMCU lalu mengirim sinyal ke Relay untuk switching otomatis daya PLTS ke daya PLN, pada Kondisi ini daya PLN menyuplai ke beban dan lampu indikator PLN menyala dan Aplikasi Blynk memberi notifikasi dengan Teks "Kondisi Daya PLTS terhubung - PLN terputus" . berikut gambar indikator PLN on pada Panel box mini.
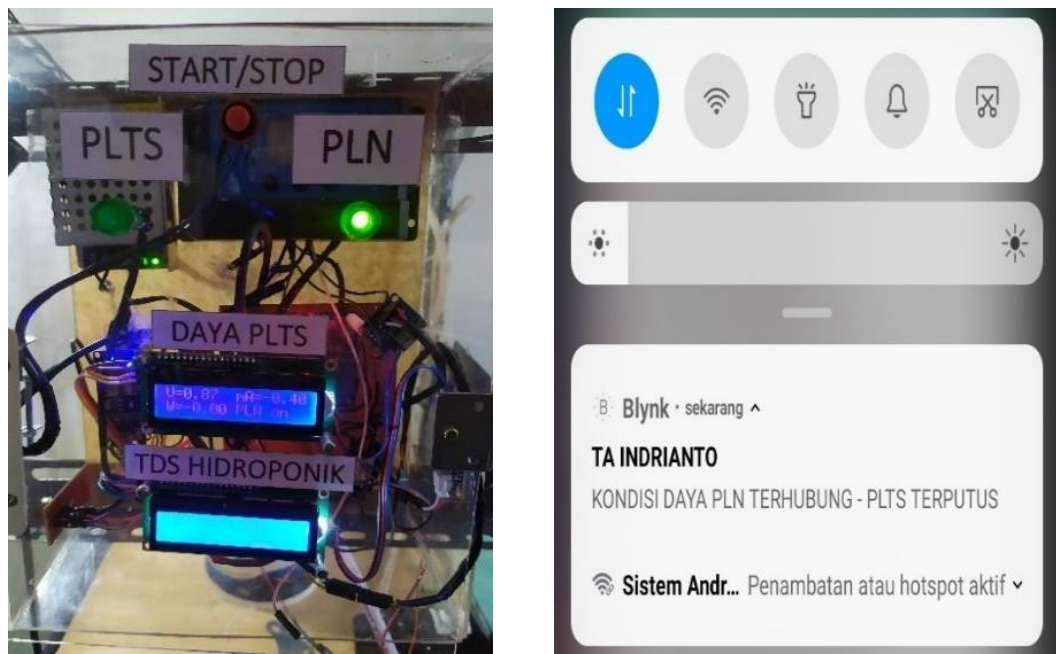

Gambar 7. Kondisi Daya PLN terhubung - PLTS terputus 
Procedia of Engineering and Life Science Vol. 1 No.1 March 2021

Seminar Nasional \& Call Paper Fakultas Sains dan Teknologi (SENASAINS 1st)

Universitas Muhammadiyah Sidoarjo

4. Ketika Tegangan PLTS pulih kembali lebih >10VDC, maka Sensor INA219 akan mengirim data ke NodeMCU lalu mengirim sinyal ke Relay untuk switching otomatis daya PLN ke daya PLTS , pada Kondisi ini daya PLTS menyuplai ke beban dan lampu indikator PLTS menyala dan Aplikasi Blynk memberi notifikasi dengan Teks "Kondisi PLTS terhubung - PLN terputus".
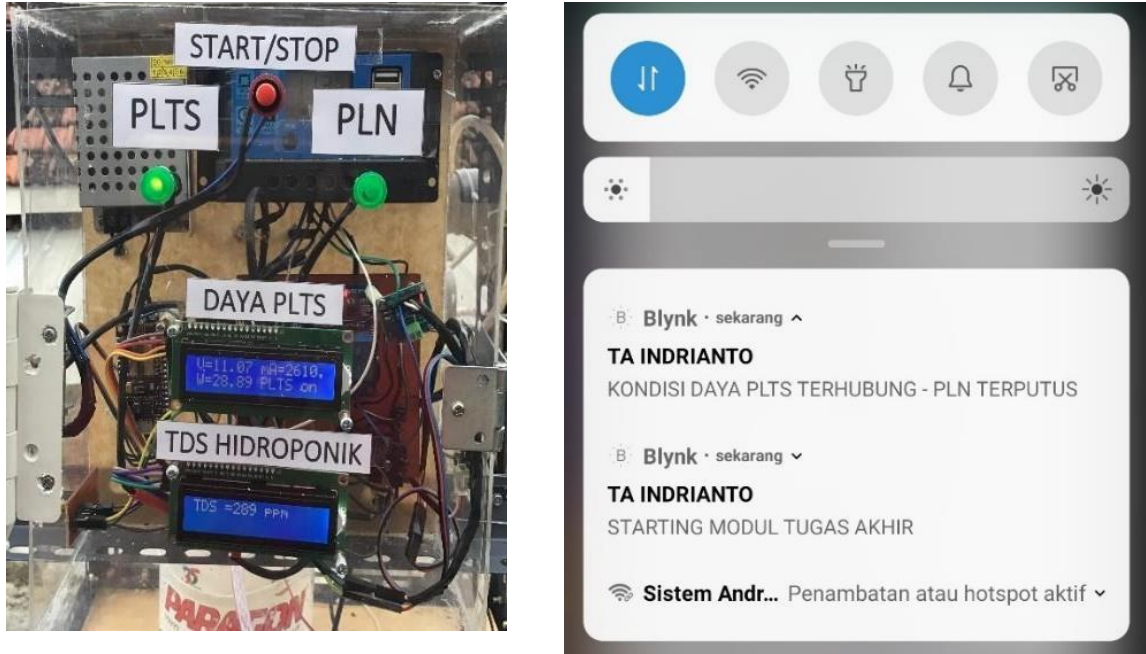

Gambar 8. Kondisi Daya PLTS terhubung - PLN terputus

Tabel 1. Pengujian Sistem ATS(Automatic Transfer Switch)

\begin{tabular}{|c|c|c|c|c|c|c|c|c|c|}
\hline \multirow[t]{2}{*}{ Jam } & \multirow[t]{2}{*}{ Cuaca } & \multicolumn{2}{|c|}{$\begin{array}{c}\text { Kondisi } \\
\text { aliran listrik }\end{array}$} & \multicolumn{3}{|c|}{$\begin{array}{l}\text { Pengukuran Output } \\
\text { PLTS (Aki) }\end{array}$} & \multicolumn{3}{|c|}{$\begin{array}{l}\text { Pengukuran Output } \\
\text { PLN (Adaptor) }\end{array}$} \\
\hline & & PLTS & PLN & $\mathrm{V}$ & A & $\mathrm{W}$ & $\mathrm{V}$ & A & W \\
\hline 08.00 & Mendung & $\mathrm{ON}$ & OFF & 12,04 & 2,1 & 25,28 & & & \\
\hline 08.30 & Cerah & $\mathrm{ON}$ & OFF & 12,6 & 2,3 & 29 & & & \\
\hline 09.00 & Cerah & $\mathrm{ON}$ & OFF & 12,80 & 2,58 & 33,02 & & & \\
\hline 09.30 & Cerah & $\mathrm{ON}$ & OFF & 12,7 & 2,5 & 31,8 & & & \\
\hline 10.00 & Cerah & $\mathrm{ON}$ & OFF & 12,77 & 2,44 & 31,16 & & & \\
\hline 10.30 & Cerah & $\mathrm{ON}$ & OFF & 12,9 & 2,6 & 33,5 & & & \\
\hline 11.00 & Cerah & $\mathrm{ON}$ & OFF & 13,7 & 2,65 & 36,31 & & & \\
\hline 11.30 & Cerah & $\mathrm{ON}$ & OFF & 14,0 & 2,7 & 37,8 & & & \\
\hline 12.00 & Cerah & $\mathrm{ON}$ & OFF & 13,8 & 2,6 & 35,9 & & & \\
\hline 12.30 & Cerah & $\mathrm{ON}$ & OFF & 13,6 & 2,6 & 35,4 & & & \\
\hline 13.00 & Cerah & $\mathrm{ON}$ & OFF & 13,88 & 2,5 & 34,7 & & & \\
\hline 13.30 & Cerah & $\mathrm{ON}$ & OFF & 13,72 & 2,5 & 34,3 & & & \\
\hline 14.00 & Cerah & $\mathrm{ON}$ & OFF & 13,5 & 2,44 & 32,94 & & & \\
\hline 14.30 & Mendung & $\mathrm{ON}$ & OFF & 13,2 & 2,3 & 30,4 & & & \\
\hline 15.00 & Mendung & $\mathrm{ON}$ & OFF & 12,4 & 2,12 & 26,29 & & & \\
\hline 15.30 & Hujan & $\mathrm{ON}$ & OFF & 11,8 & 2,03 & 23,95 & & & \\
\hline 16.00 & Hujan & $\mathrm{ON}$ & OFF & 11,4 & 2,0 & 22,8 & & & \\
\hline 16.30 & Hujan & $\mathrm{ON}$ & OFF & 10,6 & 1,9 & 20,1 & & & \\
\hline 17.00 & Mendung & OFF & $\mathrm{ON}$ & & & & 11,96 & 1,4 & 16,74 \\
\hline 17.30 & Mendung & OFF & $\mathrm{ON}$ & & & & 11,98 & 1,2 & 14,38 \\
\hline 18.00 & Mendung & OFF & $\mathrm{ON}$ & & & & 11,88 & 1,2 & 14,26 \\
\hline \multicolumn{4}{|c|}{ Rata-Rata } & 11,02 & 2,04 & 26,41 & 11,94 & 1,27 & 15,13 \\
\hline
\end{tabular}


Procedia of Engineering and Life Science Vol. 1 No.1 March 2021

Seminar Nasional \& Call Paper Fakultas Sains dan Teknologi (SENASAINS 1st)

Universitas Muhammadiyah Sidoarjo

Pada Tabel 1. Diatas diketahui bahwa Daya PLTS menyuplai ke beban Pompa dari pukul 08.00 - 16.30, padaPukul 16.30 Sistem ATS memindahkan (Switching) Daya PLTS ke daya Backup PLN secara Otomatis dikarenakan Tegangan sudah melemah <10VDC dan Daya Backup PLN menyuplai daya ke beban Pompa Submersible beserta NonSubmersible supaya tetap terhubung untuk menyuplai air ke Tanaman Hidroponik.
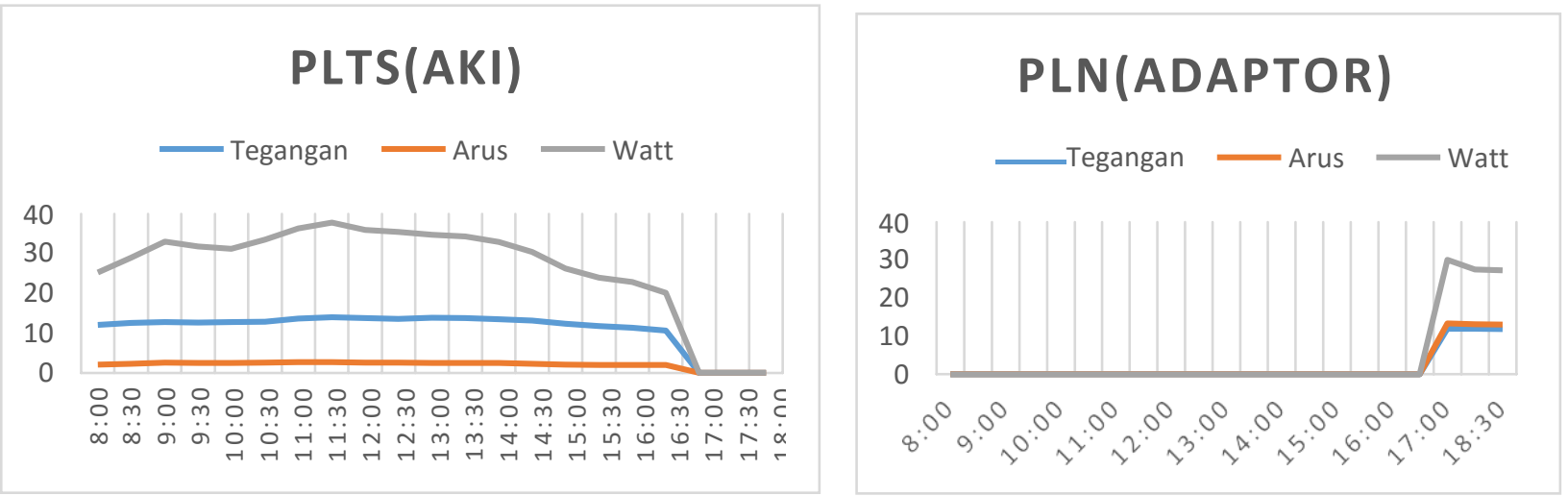

Gambar 9. Grafik Pengukuran keluaran Daya PLTS dan PLN

Pada Gambar Grafik 9. diatas dilakukan pengukuran Keluaran pada daya PLTS dan PLN dimulai Pukul 08.00 sampai 18.00 . pada Grafik tersebut didapatkan data yang dimana Keluaran Tegangan paling tinggi pukul 11.30 sebesar 14V dikarenakan Modul PV terkena Radiasi Panas Matahari tinggi saat cuaca yang sangat Terik dan Keluaran Tegangan terendah sebesar 10,6V karena Modul PV tidak bekerja optimal saat Cuaca Hujan . Sistem ATS melakukan pemindahan (Switching) Otomatis daya PLTS ke PLN, Kondisi daya PLN terhubung dimulai Pukul 17.00 sampai

18.00 dan pada pengukuran Keluaran dari Adaptor PLN didapatkan data Rata-Rata Daya sebesar 15,13W .

\section{Pengujian Sensor INA219}

Pengujian Sensor INA219 dapat membaca nilai keluaran 2 Paramater yaitu Tegangan dan Arus dan dilakukan untuk mengetahui keakurasian sensor INA219 dengan alat yang sesungguhnya, dengan demikian akan disimpulkan keakurasianya.

Tabel 2. Pengujian Sensor INA219 pada Parameter Tegangan

\begin{tabular}{|c|c|c|c|c|c|c|c|c|c|c|c|c|c|c|c|c|c|}
\hline \multirow[t]{2}{*}{$\begin{array}{l}\mathbf{N} \\
\mathbf{0}\end{array}$} & \multirow{2}{*}{$\begin{array}{l}\text { Outpu } \\
\text { t } \\
\text { Beban }\end{array}$} & \multicolumn{2}{|c|}{$\begin{array}{l}\text { Ujicoba } \\
\text { Pertama }\end{array}$} & \multicolumn{2}{|c|}{$\begin{array}{l}\text { Ujicoba } \\
\text { Kedua }\end{array}$} & \multicolumn{2}{|c|}{$\begin{array}{l}\text { Ujicoba } \\
\text { Ketiga }\end{array}$} & \multicolumn{2}{|c|}{$\begin{array}{l}\text { Ujicoba } \\
\text { Keempat }\end{array}$} & \multicolumn{2}{|c|}{$\begin{array}{l}\text { Ujicoba } \\
\text { Kelima }\end{array}$} & \multicolumn{2}{|c|}{$\begin{array}{l}\text { Rata-Rata } \\
\text { tegangan }\end{array}$} & \multicolumn{4}{|c|}{$\begin{array}{l}\text { Standar } \\
\text { Deviasi }\end{array}$} \\
\hline & & $\begin{array}{l}\text { Sens } \\
\text { or } \\
\text { INA } \\
219 \\
\text { (V) }\end{array}$ & $\begin{array}{l}\text { Alat } \\
\text { Stan } \\
\text { dar } \\
\text { (V) }\end{array}$ & $\begin{array}{l}\text { Sens } \\
\text { or } \\
\text { INA } \\
219 \\
\text { (V) }\end{array}$ & $\begin{array}{l}\text { Alat } \\
\text { Stan } \\
\text { dar } \\
\text { (V) }\end{array}$ & $\begin{array}{l}\text { Sens } \\
\text { or } \\
\text { INA } \\
219 \\
\text { (V) }\end{array}$ & $\begin{array}{l}\text { Alat } \\
\text { Stan } \\
\text { dar } \\
\text { (V) }\end{array}$ & $\begin{array}{l}\text { Sens } \\
\text { or } \\
\text { INA } \\
219 \\
\text { (V) }\end{array}$ & $\begin{array}{l}\text { Alat } \\
\text { Stan } \\
\text { dar } \\
\text { (V) }\end{array}$ & $\begin{array}{l}\text { Sens } \\
\text { or } \\
\text { INA } \\
219 \\
\text { (V) }\end{array}$ & $\begin{array}{l}\text { Alat } \\
\text { Stan } \\
\text { dar } \\
(V)\end{array}$ & $\begin{array}{l}\text { Sens } \\
\text { or } \\
\text { INA } \\
219 \\
\text { (V) }\end{array}$ & $\begin{array}{l}\text { Alat } \\
\text { Stan } \\
\text { dar } \\
\text { (V) }\end{array}$ & $\begin{array}{l}\text { Sens } \\
\text { or } \\
\text { INA } \\
219 \\
\text { (V) }\end{array}$ & $\begin{array}{l}\text { Alat } \\
\text { Stan } \\
\text { dar } \\
\text { (V }\end{array}$ & $\begin{array}{l}\text { Dev } \\
\text { iasi } \\
(V)\end{array}$ & $\begin{array}{l}\text { Persen } \\
\text { tase } \\
\text { ketepa } \\
\tan \%\end{array}$ \\
\hline 1 & Pompa & 12,5 & 12,6 & 12,5 & 12,6 & 12,5 & 12,6 & 12,5 & 12,6 & 12,4 & 12,5 & 12,4 & 12,5 & 0,05 & 0,17 & 0,1 & $99,3 \%$ \\
\hline & $\begin{array}{l}\text { subme } \\
\text { rsible }\end{array}$ & 1 & & 1 & & 1 & & 0 & & 6 & 8 & 9 & 9 & & & & \\
\hline 2 & Pompa & 12,4 & 12,4 & 12,4 & 12,4 & 12,4 & 12,4 & 12,4 & 12,4 & 12,4 & 12,4 & 12,4 & 12,4 & 0,03 & 0,03 & 0,06 & $99,6 \%$ \\
\hline & $\begin{array}{l}\text { non } \\
\text { subme } \\
\text { rsible }\end{array}$ & 2 & 8 & 2 & 8 & 1 & 8 & 1 & 8 & 0 & 6 & 1 & 7 & & & & \\
\hline
\end{tabular}

Pada Tabel 2. Diatas dilakukan Pengujian Sensor INA219 untuk mengukur keluaran Tegangan pada beban 2 Pompa beserta membandingkan dengan pengukuran Multimeter dan pengujian dilakukan selama 5 kali, dimana didapatkan standar deviasi dari Sensor INA219 = 0,05 - 0,03 sedangkan standar deviasi dari alat standar = 0,17 - 0,03 , Untuk tingkat akurasi dari sensor sebesar 99,3-99,6 .

Kesimpulan dalam Pengujian Sensor INA219 dan Multimeter menunjukkan angka yang hampir sama. 
Procedia of Engineering and Life Science Vol. 1 No.1 March 2021

Seminar Nasional \& Call Paper Fakultas Sains dan Teknologi (SENASAINS 1st)

Universitas Muhammadiyah Sidoarjo

Tabel 3. Pengujian Sensor INA219 pada Parameter Arus

\begin{tabular}{|c|c|c|c|c|c|c|c|c|c|c|c|c|c|c|c|c|c|}
\hline \multirow[t]{2}{*}{$\begin{array}{l}\mathbf{N} \\
\mathbf{0}\end{array}$} & \multirow{2}{*}{$\begin{array}{l}\text { Outpu } \\
\mathbf{t} \\
\text { Beban }\end{array}$} & \multicolumn{2}{|c|}{$\begin{array}{l}\text { Ujicoba } \\
\text { Pertama }\end{array}$} & \multicolumn{2}{|c|}{$\begin{array}{l}\text { Ujicoba } \\
\text { Kedua }\end{array}$} & \multicolumn{2}{|c|}{$\begin{array}{l}\text { Ujicoba } \\
\text { Ketiga }\end{array}$} & \multicolumn{2}{|c|}{$\begin{array}{l}\text { Ujicoba } \\
\text { Keempat }\end{array}$} & \multicolumn{2}{|c|}{$\begin{array}{l}\text { Ujicoba } \\
\text { Kelima }\end{array}$} & \multicolumn{2}{|c|}{$\begin{array}{l}\text { Rata-Rata } \\
\text { arus }\end{array}$} & \multicolumn{4}{|c|}{$\begin{array}{l}\text { Standar } \\
\text { Deviasi }\end{array}$} \\
\hline & & $\begin{array}{l}\text { Sens } \\
\text { or } \\
\text { INA } \\
219 \\
(\mathrm{~mA} \\
)\end{array}$ & $\begin{array}{l}\text { Alat } \\
\text { Stan } \\
\text { dar } \\
\text { (m } \\
\text { A) }\end{array}$ & $\begin{array}{l}\text { Sens } \\
\text { or } \\
\text { INA } \\
219 \\
(\mathrm{~mA} \\
)\end{array}$ & $\begin{array}{l}\text { Alat } \\
\text { Stan } \\
\text { dar } \\
\text { (m } \\
\text { A) }\end{array}$ & $\begin{array}{l}\text { Sens } \\
\text { or } \\
\text { INA } \\
219 \\
(\mathrm{~mA} \\
)\end{array}$ & $\begin{array}{l}\text { Alat } \\
\text { Stan } \\
\text { dar } \\
\text { (m } \\
\text { A) }\end{array}$ & $\begin{array}{l}\text { Sens } \\
\text { or } \\
\text { INA } \\
219 \\
(\mathrm{~mA} \\
)\end{array}$ & $\begin{array}{l}\text { Alat } \\
\text { Stan } \\
\text { dar } \\
\text { (m } \\
\text { A) }\end{array}$ & $\begin{array}{l}\text { Sens } \\
\text { or } \\
\text { INA } \\
219 \\
(\mathrm{~mA} \\
)\end{array}$ & $\begin{array}{l}\text { Alat } \\
\text { Stan } \\
\text { dar } \\
\text { (m } \\
\text { A) }\end{array}$ & $\begin{array}{l}\text { Sens } \\
\text { or } \\
\text { INA } \\
219 \\
(\mathrm{~mA} \\
)\end{array}$ & $\begin{array}{l}\text { Alat } \\
\text { Stan } \\
\text { dar } \\
\text { (m } \\
\text { A) }\end{array}$ & $\begin{array}{l}\text { Sens } \\
\text { or } \\
\text { INA } \\
219\end{array}$ & $\begin{array}{l}\text { Alat } \\
\text { Stan } \\
\text { dar }\end{array}$ & $\begin{array}{l}\text { Dev } \\
\text { iasi }\end{array}$ & $\begin{array}{l}\text { Persen } \\
\text { tase } \\
\text { ketepa } \\
\tan \%\end{array}$ \\
\hline 1 & $\begin{array}{l}\text { Pompa } \\
\text { subme } \\
\text { rsible }\end{array}$ & 237 & 230 & 258 & 250 & 262 & 255 & 265 & 250 & 250 & 243 & $\begin{array}{c}254 \\
4\end{array}$ & $\begin{array}{c}245 \\
6\end{array}$ & 3,92 & 5,22 & 8,8 & $97 \%$ \\
\hline 2 & $\begin{array}{l}\text { Pompa } \\
\text { non } \\
\text { subme } \\
\text { rsible }\end{array}$ & 480 & 465 & 561 & 540 & 478 & 458 & 544 & 525 & 568 & 545 & $\begin{array}{c}526 \\
2\end{array}$ & $\begin{array}{c}506 \\
6\end{array}$ & $\begin{array}{c}18,6 \\
7\end{array}$ & $\begin{array}{c}11,0 \\
5\end{array}$ & 19,6 & $97 \%$ \\
\hline
\end{tabular}

Pada Tabel 3. Diatas dilakukan Pengujian Sensor INA219 untuk mengukur keluaran Arus pada beban 2 Pompa ,beserta membandingkan dengan pengukuran Multimeter dan pengujian dilakukan selama 5 kali, , dimana didapatkan standar deviasi dari Sensor INA219 = 3,92 sedangkan standar deviasi dari alat standar $=5,22$ Untuk tingkat akurasi dari sensor sebesar $97 \%$.

Kesimpulan dalam Pengujian Sensor INA219 dan Multimeter menunjukkan error pembacaan sebesar $3.0 \%$

\section{Pengujian Sensor TDS}

Sensor Analog TDS(Total Dissolved Solid) yang berfungsi mengukur bahan padat yang terdapat didalam bak air dengan satuan PPM(parts-per million), Pengujian ini dilakukan selama 10 jam dari pukul 08.00 - 18.00 . Jika banyak bahan padat didalam suatu bak air maka pengukuran Output PPM semakin tinggi dan Jika semakin sedikit bahan padat yang larut maka semakin rendah nilai pengukuran TDS. Berikut Tabel Pengukuran TDS pada air Hidroponik .

Tabel 4. Pengujian Sensor TDS

\begin{tabular}{lccl}
\hline No & Jam & $\begin{array}{c}\text { Nilai keluraran } \\
\text { Sensor TDS } \\
\text { (PPM) }\end{array}$ & Kondisi Air \\
\hline $\mathbf{1}$ & 08.00 & 238 & Bersih \\
\hline $\mathbf{2}$ & 08.30 & 249 & Bersih \\
\hline $\mathbf{3}$ & 09.00 & 251 & Bersih \\
\hline $\mathbf{4}$ & 09.30 & 255 & Bersih \\
\hline $\mathbf{5}$ & 10.00 & 287 & Bersih \\
\hline $\mathbf{6}$ & 10.30 & 299 & Bersih \\
\hline $\mathbf{7}$ & 11.00 & 293 & Bersih \\
\hline $\mathbf{8}$ & 11.30 & 280 & Bersih \\
\hline $\mathbf{9}$ & 12.00 & 285 & Bersih \\
\hline $\mathbf{1 0}$ & 12.30 & 288 & Bersih \\
\hline $\mathbf{1 1}$ & 13.00 & 294 & Bersih \\
\hline $\mathbf{1 2}$ & 13.30 & 296 & Bersih \\
\hline $\mathbf{1 3}$ & 14.00 & 300 & Bersih \\
\hline $\mathbf{1 4}$ & 14.30 & 313 & Bersih \\
\hline $\mathbf{1 5}$ & 15.00 & 298 & Bersih \\
\hline $\mathbf{1 6}$ & 15.30 & 302 & Bersih \\
\hline $\mathbf{1 7}$ & 16.00 & 312 & Bersih \\
\hline $\mathbf{1 8}$ & 16.30 & 320 & Bersih \\
\hline $\mathbf{1 9}$ & 17.00 & 316 & Bersih \\
\hline $\mathbf{2 0}$ & 17.30 & 319 & Bersih \\
\hline $\mathbf{2 1}$ & 18.00 & 324 & Bersih \\
\hline $\mathbf{R a t a}-$ Rata & 291,38 & \\
\hline & & & \\
\hline
\end{tabular}


Procedia of Engineering and Life Science Vol. 1 No.1 March 2021

Seminar Nasional \& Call Paper Fakultas Sains dan Teknologi (SENASAINS 1st)

Universitas Muhammadiyah Sidoarjo

Pada Tabel 4. diatas didapatkan data Pembacaan Sensor TDS pada kualitas air Hidroponik dengan Rata-rata sebesar 291,38 PPM. Berikut Gambar Grafik Pengukuran PPM air Hidroponik.

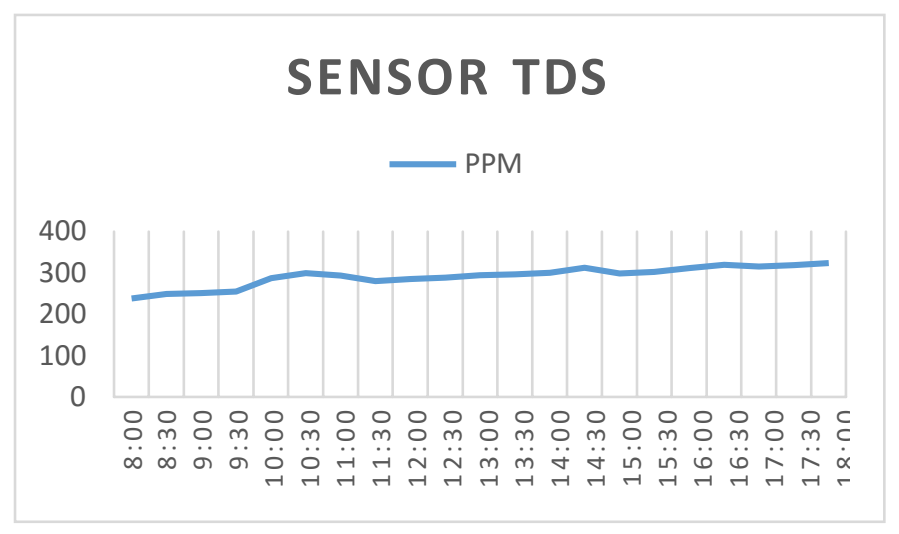

Gambar 10. Pengukuran Nilai PPM pada Air Hidroponik

Dari Gambar Grafik 12 diatas didapatkan data bahwa semakin bertambahnya waktu kepadatan air semakin tinggi pada pengukuran PPM dengan Sensor TDS . Rata-Rata PPM yang diukur selama 10 jam sebesar 291,38 PPM , Nilai PPM tertinggi pada pukul 18.00 sebesar 324 PPM dan Nilai PPM terendah pada Pukul 08.00 sebesar 238 PPM . Dengan semakin tinggi Nilai PPM Maka bahan Padat yang terdapat pada Air yang mengalir di Hidroponik semakin tinggi.

\section{KESIMPULAN}

Berdasarkan pengukuran, pengujian, perhitungan dan analisis data pada SISTEM ATS HYBRID DENGAN DAYA PLTS DAN PLN UNTUK POMPA HIDROPONIK BERBASIS IOT maka dapat disimpulkan bahwa :

1. Kinerja dari Sistem ATS(Automatic Transfer Switch) cukup efisien dengan menggunakan Mikrokontroller NodeMCU ESP8266 dengan melakukan Switching otomatis jika daya PLTS melemah <10V maka Relay memutus Aliran listrik daya PLTS dan Menghubungkan Aliran daya PLN untuk menyuplai ke beban supaya Motor Pompa DC Tetap menyala untuk menyuplai air ke Tanaman Hidroponik.

2. Dengan terkoneksi Aplikasi Blynk lewat internet, Pengguna sangat mudah melakukan Monitoring setiap waktu .

3. Daya PLTS menyuplai aliran listrik ke beban pompa selama $8 \frac{1}{2}$ Jam dari pukul 08.00 - 16.30 dan Daya PLN menyuplai aliran listrik untuk menggantikan Daya PLTS yang sudah melemah dari Pukul 16.30 - 18.00 .

4. Sensor INA219 berfungsi dengan baik dengan tingkat akurasi Arus sebesar $97 \%$ dan Tegangan mencapai 99,3 - 99,6 \%. Dan Error Pembacaan Arus Sebesar $3 \%$ beserta Tegangan Sebesar $1 \%$.

5. Pembacaan pada Sensor TDS pada kualitas air Hidroponik dengan Rata-rata sebesar 291,38 PPM.

6. Keluaran Daya PLTS sangat bergantung dengan Intensitas Cahaya Matahari .Jika semakin tinggi intensitas Cahaya saat Cuaca Terik maka menghasilkan keluaran Tegangan dan Arus yang tinggi dan akan mempercepat pengisian pada Baterai/Aki dan Jika semakin rendah intensitas maka semakin rendah pula Keluaran Daya PLTS yang dihasilkan.

\section{REFERENSI}

[1] J. Jamaaluddin, "Perencanaan Sistem Pentanahan Tenaga Listrik Terintegrasi Pada Bangunan," J. Electr. Electron. Eng., vol. 1, no. 1, p. 29, 2017, doi: 10.21070/jeee-u.v1i1.375.

[2] Jamaaluddin, I. Robandi, and I. Anshory, "A very short-term load forecasting in time of peak loads using interval type-2 fuzzy inference system: A case study on java bali electrical system," J. Eng. Sci. Technol., 2019.

[3] sugeng ariyono Mardiyono, "PEMANFAATAN TEKNOLOGI KONVERSI ENERGI SURYA UNTUK HIDROPONIK PADA SMP ALAM AR RIDHO,” vol. 7, no. April, pp. 19-26, 2018.

[4] M. F. Rizal, "PENERAPAN PANEL FOTOVOLTAIK," 2008.

[5] "Pemanfaatan Pompa Air-PLTS UNTUK Pemenuhan Ketersediaan Air Penyiram Tanaman pada Program Ecogarden SDIT Al Uswah.”. 
Procedia of Engineering and Life Science Vol. 1 No.1 March 2021

Seminar Nasional \& Call Paper Fakultas Sains dan Teknologi (SENASAINS 1 ${ }^{\text {st }}$ )

Universitas Muhammadiyah Sidoarjo

[6] A. Supriyadi, J. Jamaaluddin, T. Elektro, and U. Muhammadiyah, "ANALISA EFISIENSI PENJEJAK SINAR MATAHARI DENGAN MENGGUNAKAN KONTROL ATMEGA16," pp. 8-15.

[7] A. Majid, R. Hardiansyah, P. Studi, and T. Elektro, "ALAT AUTOMATIC TRANSFER SYSTEM (ATS)SEBAGAI SISTEM KELISTRIKAN HYBRID SEL SURYA PADA RUMAH TANGGA,” vol. 2, no. 2, pp. 172-178, 2018.

[8] A. W. Indrawan, S. Pranoto, and A. R. Sultan, "Rancang Bangun Automatic Transfer Switch ( ATS ) Pada PLTS dan PLN serta Genset."

[9] F. H. Hasan, "Rancang Bangun MPPT Dengan DC-DC Buck Converter Pada Panel Surya dengan Beban Pompa Air DC," pp. 1-43, 2017.

[10] N. Hidayati, L. Dewi, M. F. Rohmah, and S. Zahara, "Prototype Smart Home Dengan Modul NodeMCU ESP8266 Berbasis Internet of Things (IoT)," Tek. Inform. Univ. Islam Majapahit, pp. 1-9, 2018.

[11] A. B. Lim et al., "SISTEM KENDALI HIDROPONIK DALAM RUANGAN BERBASIS RASPBERRYPI," 2020 . 